\title{
Restitution of Religious Education in Lithuania
}

\author{
Vaineta Juškienè
}

\begin{abstract}
The Soviet government separated the Church from the process of education, closed religious schools, eliminated religious content from curriculum, and prohibited group catechesis. The Lithuanian Awakening at the end of 1980s and early 1990s restored religious education, important to a large segment of the Catholic population. However, implementation of religious education lacked both legislative and practical foundations. The research questions raised in this context are: Which essential prerequisites enabled restitution of religious education in the 1990s? and What main results in the sphere of restoration of religious education were achieved from the beginning of independence until 2004? This study analyses academic literature and uses documents as research sources. Sources reveal that at the beginning of the Awakening, the Lithuanian government, the Academy of Sciences, and Sajüdis encouraged citizens, organisations, and social groups to offer suggestions for amendments to the Soviet Lithuanian Constitution. Both the Catholic clergy and congregations responded to the invitation. Their active participation in the legitimation of religious education nurtured preconditions for restitution, even on the eve of restoration of independence. From a legal perspective, the status of religious education and incorporation of the Catholic Church into the education process of the country was finally solidified in 2000 upon ratification of the international agreement between the Holy See and the Republic of Lithuania on cooperation in education and culture. At the beginning of the $21^{\text {st }}$ century, religious education in Lithuania had a legal basis and a firm status in the system of education and a network of Catholic schools was created (partly re-created).
\end{abstract}

Keywords: Catholic Church, religious education, Catholic schools

\section{Introduction}

During the Soviet era, religious education was erased from the education system in Lithuania: the Soviet government separated Church from state, closing functioning Catholic schools and excluding religion lessons from curriculum. In 1976, new regulations for religious communities expanded, introducing even greater bans: group catechesis was prohibited and a regulation allowing people to decide about their religious beliefs only after the age of 18 was adopted. No attention was paid to requests by the clergy to harmonise these regulations with Canon Law of the Catholic Church. ${ }^{1}$ Consequently, religious education could be fostered secretly only within families. Research

1 Lietuvos Kataliku Bažnyčios Kronika [Chronicle of the Catholic Church], vol. 10, Chicago, L. K. Religinès Šalpos Rèmejai, 1989. 
indicates ${ }^{2}$ that religious upbringing in families had little effect: parents were not familiar with the Catholic faith and the restrictions and negative attitudes towards the Church made Catholic education virtually impossible. Religious communities that performed catechesis activities underground were restricted and persecuted.

In this context, the idea of freedom of religion became an integral part of the concept of Lithuanian independence. One of the main conditions of freedom was good quality religious education, an important issue in the period of the Lithuanian Awakening. The idea of restitution of religious education was especially welcome among the Christian community and representatives of the Church. Integration of religious lessons in the process of education represented one of the clearest signs of freeing Lithuanian schools from Soviet ideology. At the same time, consequences of the former regime were particularly destructive for spiritual life, and implementation of religious ideas de facto lacked both legislative and practical foundations.

Issues surrounding regaining religious freedom and its diverse expressions have been researched by Lithuanian educologists, ${ }^{3}$ but their work is usually only partly concerned with the restitution of religious education, the main focus of this article. A more comprehensive illustration of the development and implementation of the ideas of recreation of religious education is unfolded through analysis of state documents. Research questions are raised in this context: Which essential prerequisites enabled implementation of restitution of religious education from the end of the 1980s to 2004, and what were the main results in the sphere of restoration of religious education achieved from the restoration of independence to 2004? The subject of this article is limited to Catholic religious education. This limitation was chosen because of the religious composition of the inhabitants of Lithuania, which is dominated by the Roman Catholic faith. ${ }^{4}$ I analysed academic literature and documents

2 A. Zulumskyte, J. Lipkiené, 'Katalikišku mokyklu raida XX a. Lietuvos švietimo kontekste' [Development of Catholic schools in the context of education in Lithuania in the $20^{\text {th }}$ century], Lietuviu kataliku mokslo akademijos metraštis [Annual of Lithuanian Catholic Academy of Science], vol. 22, 2003, pp. 445-458.

3 O. Tijūnèlienė, V. Kaunaité, 'Jaunesnio mokyklinio amžiaus vaikų katalikų religinio, dorinio ugdymo aspektai' [Aspects of Catholic religious and moral education of younger schoolchildren], Vakaru Lietuvos katalikiškoji kultüra IV [Catholic culture of Western Lithuania IV], Klaipeda, KU leidykla, 2001, pp. 64-72; A. Zulumskyte, G. Overlingienė, 'Tikybos pamoku pasirinkimo motyvacija ir jos kaita 6-12 klasese' [Reasons for choosing classes of Catholic religion and their changes in 6 th to $12^{\text {th }}$ grades], Soter, vol. 8, no. 36, 2002, pp. 227-235; A. Zulumskyte, 'Tẻvų požiūris ị tikybos mokymą mokykloje' [Parents' attitude towards teaching religion at school], Lietuviu kataliku mokslo akademijos suvažiavimo darbai: LKMA metraščio priedas [Work of the Convention of Lithuanian Catholic Academy of Science: Supplement to LCAS Annual], Vilnius, Kataliku akademija, 2005, pp. 1563-1570.

4 According to statistics, Lithuania was homogeneous both in pre- and post-Soviet periods. During the Soviet era, no analysis of the composition of residents according to their religious faith was possible. No questions about religious belief were asked in either censuses or in any sociological research. To discuss changes in religion in society from a historical aspect, it is necessary to use interwar data. The 1923 census indicates that $85.72 \%$ of all residents were 
that revealed the essential aspects and stages of Church and state educational policies in the process of restitution of religious education.

\section{Beginnings of restoration of religious education}

The idea for official restoration of religious education in Lithuania appeared at the advent of regaining Lithuanian independence together with other requirements of the Awakening. The Lithuanian government, Academy of Sciences, and Sajüdis encouraged citizens, organisations, and social groups to submit suggestions for amendments to the Soviet Lithuanian (LSSR) Constitution. Both Catholic clergy and congregations responded to this invitation. In 1988, among other requirements presented to the Presidium of the Supreme Soviet of the LSSR and Mikhail Gorbachev, Secretary General of the Communist Party of the USSR, was the religion issue. The 23 May 1988 appeal to Gorbachev by priests of Panavėžys diocese requested the USSR "not restrict preparation of children for the Sacraments and allow religious education of children and youth." ${ }^{5}$ In a priest symposium on 3 August 1988, Cardinal Vincentas Sladkevičius encouraged the clergy to initiate catechesis for children and religious education of youth before receiving approval from the Committee for Religious Matters or a special directive from the bishops. ${ }^{6}$ At the same time, clergy from Vilkaviškis diocese sent a note to Gorbachev requesting equal opportunities for religious parents as well as non-religious parents to teach their beliefs to their children. On 11 September 1988, Lithuanian bishops presented the Presidium of the Supreme Soviet of the LSSR a request to allow congregations to establish religious schools or organize supplementary religious education.

According to sources, claims for religious education were becoming more intensive and concrete. ${ }^{7}$ In their appeal to Gorbachev, Lithuanian believers asked for permission to allow priests and qualified laymen to systematically teach religion and morality/ethics to pupils in schools, boarding schools, and churches. ${ }^{8}$ The first religion lessons for pupils in state schools started as early as the autumn of 1989. According to Cardinal Sladkevičius's letter to priests,

Catholic. Changes in territorial and social circumstances make that data difficult to compare to the analysed period, but the 2001 census reveals a similar number of Catholics $-79 \%$. See Lietuvos gyventojai: struktūra ir demografine raida [Population of Lithuania: Composition and demographic development], Vilnius, Statistikos departamentas prie Lietuvos Respublikos Vyriausybès, 2006, pp. 70-75.

5 Lietuvos Katalikų Bažnyčios Kronika [Chronicle of the Catholic Church], vol. 10, Chicago, L. K. Religinès Šalpos Rèmèjai, 1989, p. 183.

6 Ibid., p. 160.

7 A. Zulumskyte, J. Lipkienè, 'Katalikiškų mokyklų raida XX a. Lietuvos švietimo kontekste' [Development of Catholic Schools in the context of education in Lithuania in the $20^{\text {th }}$ century], Lietuviu kataliku mokslo akademijos metraštis [Annual of Lithuanian Catholic Academy of Science], vol. 22, 2003, pp. 445-458.

8 Lietuvos Katalikų Bažnyčios Kronika [Chronicle of the Catholic Church], vol. 10, Chicago, L. K. Religinès Šalpos Rèmëjai, 1989, p. 160. 
this activity was a response to requests from believers and in reaction to new, favourable conditions. ${ }^{9}$

On 29 November 1989, LSSR Minister of Education Zabulis and Lithuanian Cardinal Sladkevičius signed a joint statement allowing parish priests to establish parish schools. Schools were ordered to provide, if requested by parents, a space for parish schools in state schools and to establish favourable conditions for teaching religion. The document stated that the Conference of Bishops was to appoint teachers of religion, deal with curriculum and personnel issues for religious education, and inform the Ministry of Education about their decisions. ${ }^{10}$ This document laid the foundation for the legitimation of religious education in schools. Researchers of religious expression during this period ${ }^{11}$ note that in comparison to other Soviet republics, the Lithuanian government placed the greatest pressure in terms of lessons on religion and were successful in introducing these lessons first.

\section{Legitimation of religious education in comprehensive schools}

In spring 1991, the Lithuanian Supreme Council began debating the draft Law on Education. Although religion lessons were already being taught in schools, this issue caused intense discussions. The new Law on Education, passed on 25 June1991, strengthened the legal status of religion lessons: it stated that state education institutions had to provide religious instruction upon parents' (including foster-parents) request, in accordance with the religion practiced in the immediate or extended family. Pupils who did not attend religion lessons would be taught other subjects concurrently - moral or civic education. Religion was taught by persons authorised by religious authorities. ${ }^{12}$ These requirements were not significantly altered by any later amendments to the Law on Education.

Review of the reintroduction of teaching religion in neighbouring countries reveals that analogous provisions were included in the Law on Education in Latvia in 1998; in 1996, Estonian parents were granted the legal right to appeal to school authorities for religious education of their children, although schools were not obliged to grant their request. ${ }^{13}$

${ }^{9}$ P. Subačius, Dvidešimt penkeri religinès laisvés metai 1988-2013 [Twenty five years of religious freedom 1988-2013], Vilnius, LKMA Naujasis židinys-Aidai, 2015, p. 511.

${ }^{10}$ V. Aliulis, 'Tikybos mokymas ir katechetų rengimas pirmaisiais atkurtos Nepriklausomybès metais' [Teaching of religion and training of catechists in the first years after the restoration of independence], XXI amžius [21 $1^{\text {st }}$ century], no. 70, 1998, p. 4.

11 P. Subačius, Dvidešimt penkeri religinès laisvés metai 1988-2013 [Twenty five years of religious freedom 1988-2013], Vilnius, LKMA Naujasis židinys-Aidai, 2015, p. 513.

12 'Lietuvos Respublikos Švietimo įstatymas' [Republic of Lithuania Law on Education], Valstybes žinios [State News], 20.08.1991.

13 P. Subačius, Dvidešimt penkeri religinès laisvés metai 1988-2013 [Twenty five years of religious freedom 1988-2013], Vilnius, LKMA Naujasis židinys-Aidai, 2015, p. 520. 
The legal right to religious education was officially established in the Lithuanian Constitution in 1992. The Constitution provided parents and foster parents with unrestricted right to foster their children's religious and moral upbringing in accordance with their faith. ${ }^{14}$ In terms of formal education, teaching religion in state and municipal comprehensive schools was legitimised with respect to parental requests. ${ }^{15}$ The Constitution states that there is no official/state religion in Lithuania but that the state recognises traditional churches and religious organizations. State-recognized churches and religious organizations are granted legal rights and may practice their beliefs freely, conduct services, and own houses of worship, charitable institutions, and schools for training their clergy. ${ }^{16}$ Analogous religious freedoms and educational rights were embedded in the Law on Religious Communities and Associations in $1995 .^{17}$

In terms of religious education, the Lithuanian Bishops' Conference and Catechetical centres and separate dioceses in charge of religious education strove to follow the provisions of the Magisterium of the Catholic Church, which encouraged upbringing of a comprehensively mature Christian who was active in the mission of the Church and improved the wellbeing of their country and the world according to the teachings of the Gospel. ${ }^{18}$ The theoretical model of religious education was described in the three curriculum publications for comprehensive schools (1993, 1998, 2004).

Education objectives were applied to newly-issued Lithuanian religion teaching aids. The first original Lithuanian Catholic religion textbook was issued for primary schools in 1992; more intensive production of other religious education materials began in $1998 .^{19}$

\section{Reintegration of confessional schools into the education system}

From a global perspective, the Lithuanian Constitution declared that state and municipal schools are secular, which means that the status of teaching a worldview or values was ambiguous. However, it also provided for

14 'Lietuvos Respublikos Konstitucija' [Constitution of the Republic of Lithuania], Valstybès žinios [State News], 30. 11.1992, no. 33-1014, Article 26.

${ }^{15}$ Ibid., Article 40.

${ }^{16}$ Ibid., Article 43.

${ }^{17}$ Lietuvos Respublikos Religiniu bendruomeniu ir bendriju istatymas [Law on religious communities and associations of the Republic of Lithuania], 1995. Available: https://e-seimas.lrs.lt/portal/ legalAct/lt/ TAD/TAIS.21783/SCDBicfusg (accessed 27.02.20).

18 'Gravissimum Educationis', Visuotinio Vatikano II Susirinkimo dokumentai [Documents of the second Vatican Council], 1965, Available: http://www.lcn.lt/b_dokumentai/vatikano_2s/ gravissimum-educationis.html (accessed 27.02.20).

19 P. Subačius, Dvidešimt penkeri religinès laisvés metai 1988-2013 [Twenty five years of religious freedom 1988-2013], Vilnius, LKMA Naujasis židinys-Aidai, 2015, p. 505. 
the establishment of non-state institutions of education and teaching. ${ }^{20}$ This formulation legitimated, indirectly, the ability to establish confessional schools, but legal establishment methods were limited and one possibility remained establish non-state schools. Therefore, members of traditional religious communities did not have the same rights and conditions as other residents to educate their children in educational institutions in accordance with the beliefs of the family.

More flexible conditions were provided by the amendment to the Law on Education in 1998 that formalised the founding of state schools with a 'religious worldview.' The new formulation allowed the establishment of schools by several founders. Upon parent requests, state or municipal schools could be established through an agreement with a state recognised traditional religious community or upon initiative of the community, municipal council, or state institution. ${ }^{21}$ The amendments to the Law on Education legitimated a new type of school, which solidified the role of the Church in the sphere of state education. The law stated that mandatory worldview education in these schools would be entrenched in the schools' regulations that were founded by at least two of the above-mentioned. The regulations established that:

- School heads are appointed and dismissed by the corresponding state or municipal institutions upon the proposal of the religious community;

- The religious community sets requirements for worldview education curriculum and teaching personnel; and

- Affirmation of school heads and teachers is organized by both founders (based on their competence).

In order to actualise the rights of religious freedom and strengthen religious education, the Association of Catholic School Teachers was established in 1992 and the Association of Catholic Parents was founded in 1999. After restoration of independence in 1990, the first Catholic secondary school in Lithuania was established in Telšiai. In 1995, this school was named for Bishop Vincentas Borisevičius and in 2002, it gained gymnasium status. The founders were the Telšiai Diocese curia and Telšiai Municipality. In 1991, the Panevėžys Diocese curia and Monsignor Juodelis established a Catholic school in Panevėžys. In 1993, the school was named for Bishop Kazimieras Paltarokas. Later this school was also transformed into a public institution with two founders: Panevėžys Municipality and the Panevėžys Diocese curia. Alytus Town Council created Alytus Catholic secondary school in 1996 that changed its name to Alytus Saint Benedict Secondary School in 1998. In 2000, Alytus Town Council and Vilkaviškis Diocese curia agreed to be the co-founders of Alytus Saint Benedict Secondary School, which became Alytus Saint Benedict Gymnasium in 2006.

${ }_{20}$ 'Lietuvos Respublikos Konstitucija' [Constitution of the Republic of Lithuania], Valstybès žinios [State News], 30.11.1992, no. 33-1014, Article 40.

21 'Lietuvos Respublikos Švietimo İstatymo pakeitimo İstatymas' [Republic of Lithuania Law on the amendment of the Law on Education], Valstybès žinios [State News], 29.07.98, no. 67-1940, Article 10.4 . 
In 1999 in Utena, the Minister of Education and Science ordered that Utena Secondary School No. 1 merge with Catholic Saule Secondary School and the newly formed institution received gymnasium status. ${ }^{22}$ However, expansion of this type of school was not always easy. In Klaipeda, fierce discussions concerning the establishment of Pranas Mašiotas Catholic School in 1997 and the new premises that the school received in 1998 lasted for several months and were accompanied by opposition from mass media and the municipality. ${ }^{23}$

Similar to the inter-war period in Lithuania, monasteries had significant influence on the expansion of the school network. In 1989, the Little Brothers of St. Francis returned to Kretinga and nurtured the idea of recreating St. Francis Gymnasium. Upon their initiative, Kretinga Catholic Secondary School was opened in 1992. In 1998 it became a gymnasium and regained its old name, St. Francis Gymnasium. Later, it was transformed into a non-state school founded by St. Casimir Province of St. Francis Little Brothers of Lithuania. This act provided for restoration of historical continuity: after almost seventy years, the Little Brothers of St. Francis regained the right to call themselves the true and sole founders and hosts of Kretinga St. Francis Gymnasium. Analogous processes of restitution can be observed in other monasterial educational institutions.

The Jesuit School in Kaunas was re-established in 1991 and received gymnasium status in 1997. It was the first Catholic school in Lithuania to receive gymnasium status after the restoration of independence. Vilnius Jesuit Gymnasium began in 1995 and in 1999, it became a gymnasium with a sciences and humanities focus. The Order of the Jesuits founded Vilnius and Kaunas gymnasia, both not state-financed schools. In 1997 in Marijampole, upon the initiative of Marian priests, the Marian School was recreated and received gymnasium status in 2007. This educational institution was also non-state financed. ${ }^{24}$

Since the beginning of the expansion of Catholic schools in 1991, they began to join the Association of Catholic Schools. During the Association's third conference, common Catholic school regulations were passed. In 1995, the constitutive conference of the Association of Lithuanian Catholic Schools was held in Pažaislis (Kaunas). The same year, the Ministry of Justice officially registered the Association of Pedagogues of Catholic Educational Institutions of Lithuania (LKMPA), which was recognised by the Lithuanian Bishops' Conference. In 1996, LKMPA became an official member of the European Committee for Catholic Education (CEEC). During the 2004

${ }^{22}$ V. Juškienè, Lietuvos katalikiškuju gimnazijų veiklos 1918-1940 m. ir 1990-2008 m. pedagoginiai aspektai [Pedagogical aspects in activity of Lithuanian Catholic Gymnasia in 1918-1940 and 1990-2008], Klaipèda, KU leidykla, 2009, pp. 156-157.

${ }^{23}$ P. Subačius, Dvidešimt penkeri religines laisvès metai 1988-2013 [Twenty five years of religious freedom 1988-2013], Vilnius, LKMA Naujasis židinys-Aidai, 2015, p. 600.

${ }^{24}$ V. Juškienè, Lietuvos katalikiškuju gimnazijų veiklos 1918-1940 m. ir 1990-2008 m. pedagoginiai aspektai [Pedagogical aspects in activity of Lithuanian Catholic Gymnasia in 1918-1940 and 1990-2008], Klaipèda, KU leidykla, 2009, pp. 157-160. 
LKMPA conference, amendments to the statutes of the association were made, and it was reorganised into the National Association of Catholic Schools. ${ }^{25}$

In 2000, a legal safeguard was reached guaranteeing non-state Catholic schools and other schools established by traditional religious communities and offering education according to state standards the same financing as state schools. ${ }^{26}$ There was also an appeal to the Ministry of Education and Science to supplement the regulations of the network of schools. These government documents defined the activities of establishment of non-state Catholic educational institutions and their financing: Catholic school students received the same funding as other state and municipal school students.

A very important factor in the recognition of religious education was the regulation of State and Church relationships on the international level. In 2000, the Agreement between the Holy See and the Republic of Lithuania on Cooperation in Education and Culture was ratified. With this document, Lithuania undertook the following concerning Catholic education:

- provide the possibility to choose a course in religion in all state and municipal comprehensive education schools; ${ }^{27}$

- provide the same conditions for teaching Catholic religion as for other subjects; ${ }^{28}$

- provide teaching methods and tools for teaching Catholic religious studies that comply with requirements established by the Catholic Church and the Republic of Lithuania; ${ }^{29}$

- support the activities of Catholic organisations by providing state or municipal school premises and resources; ${ }^{30}$ and

- follow the requirements established by the Republic of Lithuania and the Catholic Church when appointing, supervising, and assessing the work of Catholic religion teachers. ${ }^{31}$

The document ensured the right of the Catholic Church to establish educational institutions of different types and levels or to be one of the founders. Establishment of these institutions depended on receipt of written authorisation from the Catholic Church and the Lithuanian legal authorities. Education in

${ }^{25}$ V. Juškienè, Lietuvos katalikiškuju gimnaziju veiklos 1918-1940 m. ir 1990-2008 m. pedagoginiai aspektai [Pedagogical aspects in activity of Lithuanian Catholic Gymnasia in 1918-1940 and 1990-2008], Klaipeda, KU leidykla, 2009, pp. 86-87.

26 'Lietuvos Respublikos Švietimo İstatymo 15 straipsnio papildymo ir 41 straipsnio pakeitimo Istatymas' [Republic of Lithuania Law on Supplement of Article 15 and Amendment of Article 41 of the Law on Education], Valstybès žinios [State News], 17.05.2000, no. 40-1116, Article 2.

27 Šventojo Sosto ir Lietuvos Respublikos sutartis dẻl bendradarbiavimo švietimo ir kultūros srityje [Agreement between the Holy See and the Republic of Lithuania on Cooperation in Education and Culture], 2000. Available: http://www.lcn.lt/b_dokumentai/kiti_dokumentai/ASLR-sutartis-svietimas.html, art. 2 (accessed 27.02.20).

28 Ibid., Article 1.

29 Ibid., Article 6-7.

${ }^{30}$ Ibid., Article 4.

${ }^{31}$ Ibid., Article 3; 7. 
such institutions was required to be conducted according to Catholic doctrine, while subjects of general education would be taught according to a stateapproved programme. ${ }^{32}$

The agreement between the Holy See and the Republic of Lithuania stated that state or municipal schools, established together with the Catholic Church, and approved educational programmes in non-state and non-municipal Catholic educational institutions would be funded equally to similar state or municipal schools. Funding of supplementary programmes of non-state Catholic educational institutions was assigned to the founding institution. ${ }^{33}$

School status and dependence on the founders had a direct influence on the formation of confessional schools: formally, state schools could not give priority to any one religion. In this respect, foundation of non-state schools was more favourable as it provided religious education not only to children in a specific geographic area, but also to pupils from all over the country. By the start of the $21^{\text {st }}$ century, the network of schools in Lithuania had been complemented with a quantitatively small, but qualitatively significant segment of confessional schools.

\section{Conclusion}

Analysis of sources reveals that restitution of religious education at the beginning of the post-Soviet period in Lithuania was initiated by the clergy and widely supported by congregations. Essential factors for restitution on the national level was entrenching the right to religious education in the Constitution, the Law on Education, and the Law on Religious Communities and Associations. On the international level, educational rights of the Catholic Church were set out in the Agreement between the Holy See and the Republic of Lithuania. These documents provided for and ensured legal integration of religious education into the common educational system and for the foundation of confessional schools and development of their network.

In the early $21^{\text {st }}$ century, both these aspects were already in play: religion was taught in comprehensive schools; curriculum, handbooks, and other methodical materials had been prepared and improved; and the network of confessional Catholic schools was developing. At the time, confessional schools were separated into state and non-state schools founded by two (church and state/municipality) or one (church) founder. Monastic schools tried to reestablish the historical continuity of pedagogical activities of the pre-Soviet era and integrated successfully into the educational system of restored Lithuania and were distinguished in both quantitative and qualitative processes of development of confessional schools.

\footnotetext{
32 Šventojo Sosto ir Lietuvos Respublikos sutartis dèl bendradarbiavimo švietimo ir kultūros srityje [Agreement between the Holy See and the Republic of Lithuania on Cooperation in Education and Culture], 2000, Article 8.

${ }^{33}$ Ibid., Article 9.
} 